\title{
Establishment of Aesthetic Soft Tissue Norms for Southern India Population: A Photogrammetric Study
}

\author{
Dr Snigdha Pattanaik,' Dr Sudhakar Pathuri² \\ 'Assistant Professor, Institute of Dental Sciences, Bhubaneswar, India \\ 2Professor, Vishnu Dental College, Bhimavaram, India
}

Correspondence: Dr Snigdha Pattanaik; email: dr.snigdhapattanaik@gmail.com

\section{ABSTRACT}

Objective: To establish soft tissue facial profile norms for Coastal Andhra population by means of angular measurements and to evaluate the difference between male \& female groups.

Materials \& Method: 90 individuals (45 males, 45 females) of age group 18-25 years of native coastal Andhra Pradesh, with acceptable pleasing profile, normal Class I occlusion having ideal anterior bite were selected for the study. Standard profile photographs were taken and angular photogrammetric analysis was carried out through AutoCAD software.

Result: There were significant difference in Naso-frontal angle (G-N-Nd; males: $130.64 \pm 6.27^{\circ}$; females: $140.33^{\circ} \pm 6.85^{\circ} ; \mathrm{P}=0.000$ ) and Mento-labial angle (Li-Sm-Pg: females: $127.38^{\circ} \pm 5.35^{\circ}$; males: $124.82^{\circ} \pm 6.57^{\circ} ; \mathrm{P}=0.043$ ).

Conclusion: The males of Coastal Andhra Pradesh have mild convex profile and prominent nose whereas females have mild convex profile due to recessive chin. A higher upper lip prominence was seen in males.

Key words: Coastal Andhra population, photogrammetric analysis, soft tissue angular measurement

\section{INTRODUCTION}

Attractive people are inclined to receive greater positive social response. The perception of attractive face is largely subjective with appearance, ethnicity, age, gender, culture and personality.

During early years of orthodontics, plaster models were used for treatment planning. With the advent of diagnostic techniques numerous cephalometric analyses were developed. It was assumed that by placing the skeletal parts within the range of skeletal cephalometric norms, the facial balance would be achieved. However, the treatment based on cephalometric norms in many instances may create undesirable facial changes.

This led to the evolution of direct facial examination and diagnosis technique. The assumption of this approach is treating a face to "what looks beautiful" to produce a beautiful facial result. The overriding key to diagnosis with this method lies in the clinician's perception of size, shape and position of facial soft tissue parts. This kind of treatment planning is rather subjective. ${ }^{2}$

The most recent concept of treatment planning is based on photogrammetric analysis where measurement of soft tissue facial profile is used as guideline for aesthetic treatment goal. Analysis of facial profile from photographic records provide information on morphology of the profile and its relationship with underlying dentoskeletal structures. ${ }^{3}$

It is well known that race, ethnicity, age, sex influence facial traits. ${ }^{4}$ Various authors including Stoner, ${ }^{5}$ Neger, ${ }^{6}$ Epker, Arnett and Bergman, 8,9 Peck \& Peck, ${ }^{10}$ Riveiro et al ${ }^{11}$ used soft tissue parameters in photographic and soft tissue facial analyses based on standardized photogrammetric method. Photographic method to quantify facial aesthetics has been used by Peerlings et al. ${ }^{12}$

Advantages of photogrammetric analysis include: 1. Angular measurements are not affected by photographic enlargement as in cephalometrics, 2. Every anatomical reference point can be moved freely on computer monitor using cephalometric software program to determine the most appropriate profile points, 3 . Does not require expensive equipment and complex procedures, as it offers digitized results that are easily evaluated. ${ }^{13}$

There are differences in dentofacial relationship among ethnic or racial groups. Therefore, it is important to develop standards for various populations. Little information is present regarding the soft tissue aesthetic norms for coastal Andhra 
population. Hence, the objective of the study was to establish soft tissue facial profile norms of coastal Andhra population by means of angular measurements useful for orthodontic treatment.

\section{MATERIALS AND METHOD}

A total of 90 subjects comprising 45 female and 45 male of the age 18-25 years of the native residents of Coastal Andhra Pradesh were selected for the study. The subjects were chosen among dental students who possessed aesthetically pleasing profile as selected by two orthodontists. The selected subjects had Angle's Class I occlusion having ideal overjet and overbite, with no history of previous orthodontic treatment.

Standardized profile photographs were taken in natural head position (NHP) by positioning the patients into a custom-made mechanical device having markings on one side for assessing the photo in life size and a weight of 500 gms suspended on other side by a black thread to determine the true vertical line. The patients were instructed to look straight into the mirror at the eye level. ${ }^{3}$

The method described by Scavone et al $^{14}$ for the photographic set-up and record taking was used. Photographs were taken using Canon EOS 1000D Digital SLR camera with $105 \mathrm{~mm}$ macro lens, along with a built-in flash for uniform illumination. Height of the camera was leveled to subject's body height by adjusting the tripod height. External flash lights were used to eliminate unwanted illuminations.

Photographic records were transferred to computer. Each photograph was reduced to real size, overlaid over the calibrating gauge, and orientated so that the TV line on the photograph was parallel to vertical line of the computer monitor. Using the above mentioned method, all photographic records were scaled to life size and digitized for 10 landmarks (Figure 1) with the software for Windows, Photoshop CS, Standard Ed. Adobe Systems Inc. USA and AutoCAD 2010, Autodesk, Inc. USA. Predetermined angles were measured using AutoCAD 2010 software by the same operator (Figure 2 \& Figure 3). Obtained 10 angular values were then subjected to statistical analysis to assess the difference between gender groups

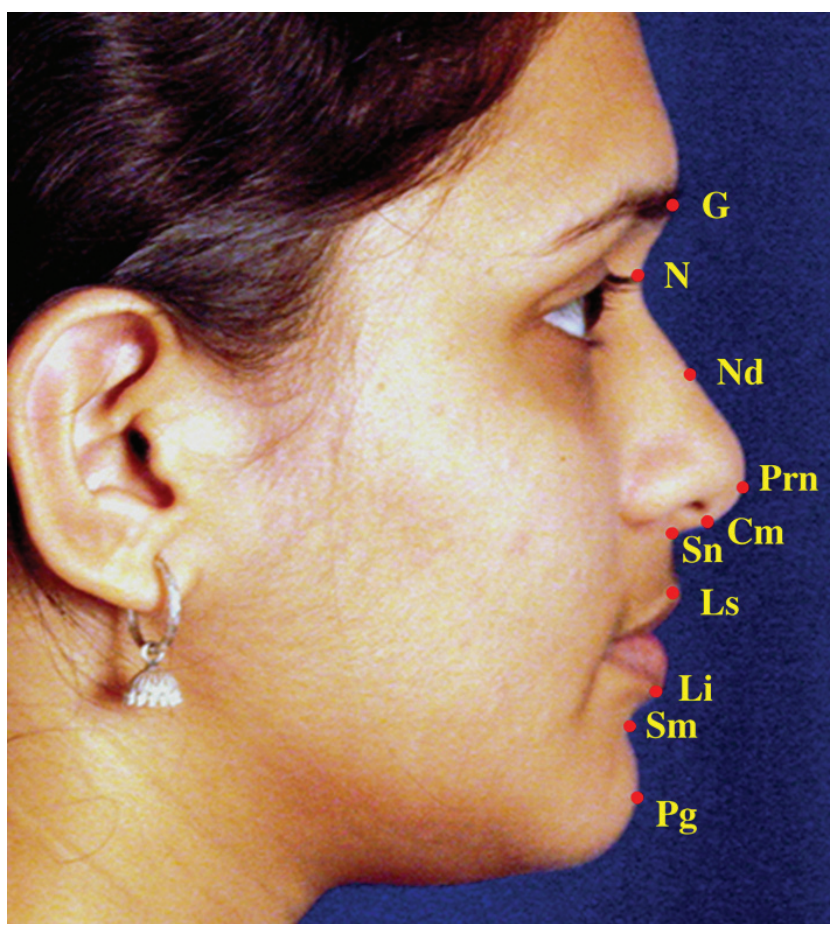

Figure 1: G: Glabella, N: Nasion, Nd: Nasal Dorsum, Sn: Subnasale, Prn: Pronasal, Cm: Columella, Ls: Labiale Superior, Li: Labiale Inferior, Sm: Supramental, Pg: Soft Tissue Pogonion

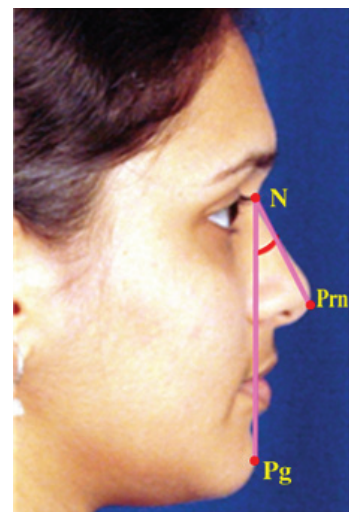

Fig 2A: Nasomental Angle

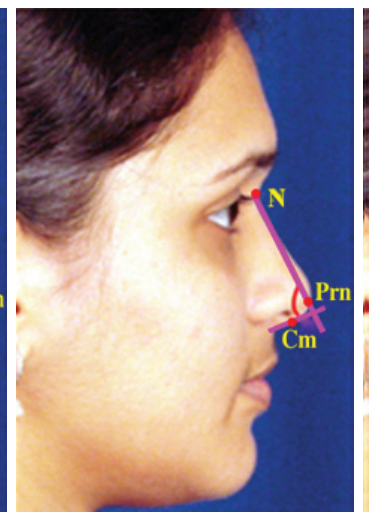

Fig 2B: Nose Tip Angle

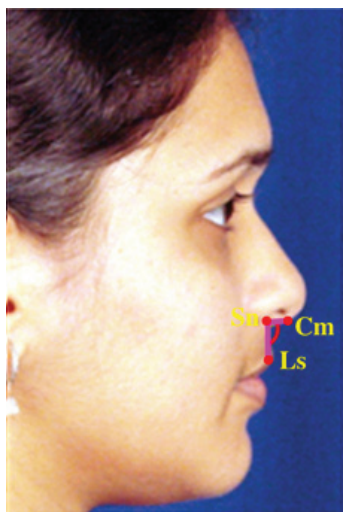

Fig 2C: Nasolabial Angle

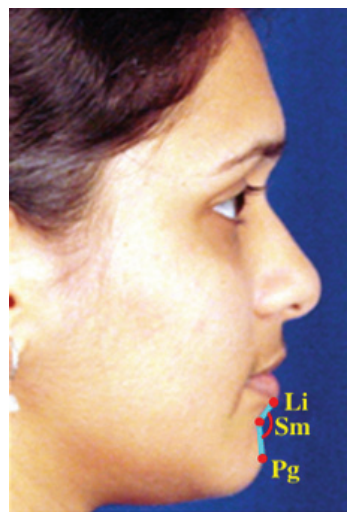

Fig 2D: Mentolabial Angle

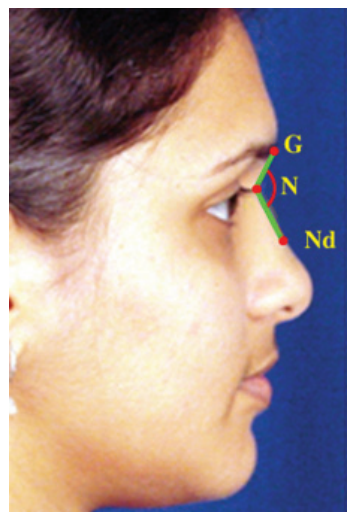

Fig 2E: Naso Frontal Angle

Figure 2: Soft tissue angular parameters 


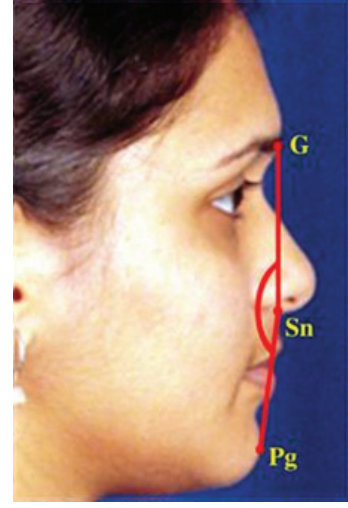

Fig 3A: Angle of facial convexity excluding nose

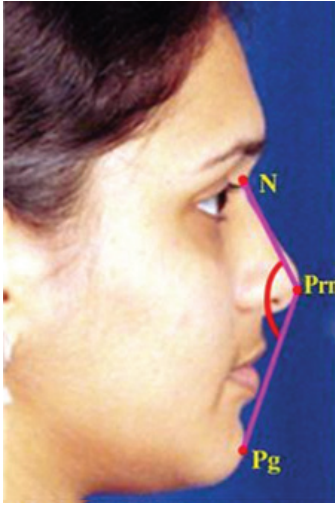

Fig 3B: Angle of facial convexity including nose

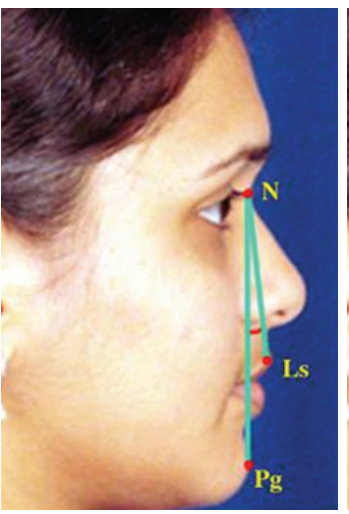

Fig 3C: Projection of the upper lip to chin

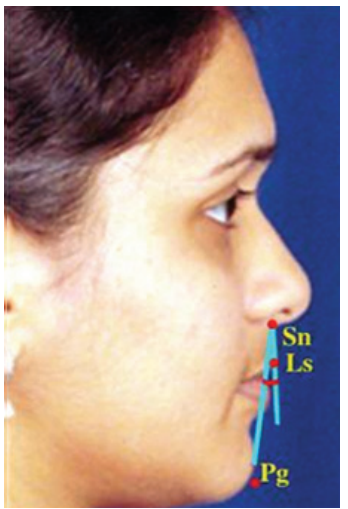

Fig 3D: Upper Lip Angle

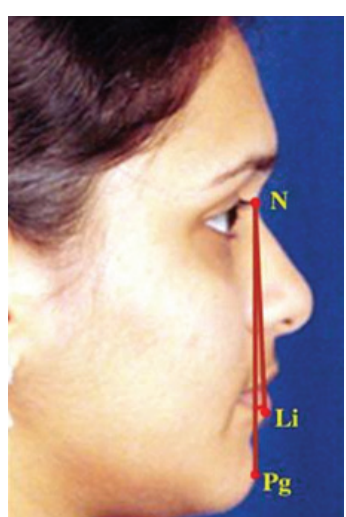

Fig 3E: Projection of the lower lip to chin

Figure 3: Soft tissue angular parameters

\section{RESULT}

The results based on soft tissue parameters depicted variability between male and female samples of coastal Andhra population. The soft tissue parameter results are tabulated in Table 1-3 and represented graphically in Graph 1-2.

There were significant gender differences in naso-frontal (G-N-Nd: males: $130.64 \pm 6.27^{\circ}$; females: $140.330 \pm 6.85^{\circ} ; \mathrm{p}$ 0.000 ) and mento-labial (Li-Sm-Pg, females: $127.38^{\circ} \pm 5.35^{\circ}$; males: $124.82^{\circ} \pm 6.57^{\circ} ; p 0.043$ ) angles. The naso-frontal angle showed that the males had a prominent nose compared to females. Mento-labial angle suggested a deep mento-labial sulcus in case of males.

The naso-mental angle (N-Prn/N-Pg) did not show any significant gender difference. The observed mean angle in males was $27.11 \pm 1.91^{\circ}$ and in females was $26.58 \pm 2.24^{\circ}$. The nose tip angle (N-Prn-Cm) showed a similar measurement between males and females with the mean angle of $77.71 \pm 11.63^{\circ}$ in males and $80.31 \pm 3.52^{\circ}$ in females.

The naso-labial angle ( $\mathrm{Cm}-\mathrm{Sn}-\mathrm{Ls})$ is also in the normal range reflecting the normal axial inclination of maxillary incisors. The observed mean angle was $98.56 \pm 5.6^{\circ}$ in males and $99.69 \pm$ $7^{\circ}$ in females.

The observed mean angle of facial convexity excluding nose (G-Sn-Pg) was $168.16 \pm 3.7^{\circ}$ in males and $166.96 \pm 4.73^{\circ}$ in females. The mean angle of facial convexity including nose (N-Prn-Pg) was $130.82 \pm 2.66^{\circ}$ in males and $131.71 \pm 3.38^{\circ}$ in females; it showed relatively straight facial profile in females.

The projection of upper lip to chin (N-Pg/N-Ls) was $8.42 \pm$ $1.62^{\circ}$ in males and $7.84 \pm 1.62^{\circ}$ in females. The upper lip angle (Sn-Ls/Sn-Pg) was $13.2 \pm 2.62^{\circ}$ in males and $13.16 \pm 2.15^{\circ}$ in females. The projection of the lower lip to chin (N-Pg/N-Li) was $4.2 \pm 1.04^{\circ}$ in males and $4.18 \pm 1.13^{\circ}$ in females.

Table 1: Angular measurements in male and female samples

\begin{tabular}{|c|c|c|c|c|}
\hline \multirow{2}{*}{ Parameter* } & \multicolumn{2}{|c|}{ Male } & \multicolumn{2}{|c|}{ Female } \\
\hline & Min & Max & Min & Max \\
\hline $\mathrm{N}-\mathrm{Prn} / \mathrm{N}-\mathrm{Pg}$ & 23 & 31 & 22 & 30 \\
\hline $\mathrm{N}-\mathrm{Prn}-\mathrm{Cm}$ & 71 & 87 & 74 & 88 \\
\hline $\mathrm{Cm}-\mathrm{Sn}-\mathrm{Ls}$ & 87 & 106 & 89 & 107 \\
\hline $\mathrm{Li}-\mathrm{Sm}-\mathrm{Pg}$ & 116 & 134 & 120 & 134 \\
\hline G-N-Nd & 119 & 138 & 137 & 154 \\
\hline G-Sn -Pg & 160 & 174 & 160 & 174 \\
\hline N-Prn-Pg & 126 & 134 & 127 & 134 \\
\hline$N-P g / N-L s$ & 6 & 11 & 6 & 13 \\
\hline$S n-L s / S n-P g$ & 7 & 15 & 8 & 15 \\
\hline $\mathrm{N}-\mathrm{Pg} / \mathrm{N}-\mathrm{Li}$ & 2 & 6 & 3 & 7 \\
\hline
\end{tabular}

*In degrees 
Table 2: Descriptive statistics and comparison of male and female parameters

\begin{tabular}{|c|c|c|c|c|c|}
\hline Parameter & Gender & Mean & SD & $t$-value & $p$-value \\
\hline \multirow{2}{*}{$\mathrm{N}-\mathrm{Prn} / \mathrm{N}-\mathrm{Pg}$} & M & 27.11 & 1.91 & \multirow{2}{*}{1.159} & \multirow{2}{*}{0.253} \\
\hline & $\mathrm{F}$ & 26.58 & 2.24 & & \\
\hline \multirow{2}{*}{$\mathrm{N}-\mathrm{Prn}-\mathrm{Cm}$} & M & 77.71 & 11.63 & \multirow{2}{*}{-1.149} & \multirow{2}{*}{0.143} \\
\hline & $\mathrm{F}$ & 80.31 & 3.52 & & \\
\hline \multirow{2}{*}{$\mathrm{Cm}-\mathrm{Sn}-\mathrm{Ls}$} & M & 98.56 & 5.6 & \multirow{2}{*}{-0.824} & \multirow{2}{*}{0.415} \\
\hline & $\mathrm{F}$ & 99.69 & 7.0 & & \\
\hline \multirow{2}{*}{$\mathrm{Li}-\mathrm{Sm}-\mathrm{Pg}$} & M & 124.82 & 6.57 & \multirow{2}{*}{-2.082} & \multirow{2}{*}{$0.043^{*}$} \\
\hline & $\mathrm{F}$ & 127.38 & 5.35 & & \\
\hline \multirow{2}{*}{$G-N-N d$} & M & 130.64 & 6.27 & \multirow{2}{*}{-6.344} & \multirow{2}{*}{$0.000^{*}$} \\
\hline & $\mathrm{F}$ & 140.33 & 6.85 & & \\
\hline \multirow{2}{*}{$G-S n-P g$} & M & 168.16 & 3.7 & \multirow{2}{*}{1.403} & \multirow{2}{*}{0.168} \\
\hline & $\mathrm{F}$ & 166.96 & 4.73 & & \\
\hline \multirow{2}{*}{$N-P r n-P g$} & M & 130.82 & 2.66 & \multirow{2}{*}{-1.376} & \multirow{2}{*}{0.176} \\
\hline & $\mathrm{F}$ & 131.71 & 3.38 & & \\
\hline \multirow{2}{*}{$N-P g / N-L s$} & M & 8.42 & 1.62 & \multirow{2}{*}{1.649} & \multirow{2}{*}{0.106} \\
\hline & $\mathrm{F}$ & 7.84 & 1.62 & & \\
\hline \multirow{2}{*}{$S n-L s / S n-P g$} & M & 13.2 & 2.62 & \multirow{2}{*}{0.09} & \multirow{2}{*}{0.928} \\
\hline & $\mathrm{F}$ & 13.16 & 2.15 & & \\
\hline \multirow{2}{*}{$\mathrm{N}-\mathrm{Pg} / \mathrm{N}-\mathrm{Li}$} & M & 4.2 & 1.04 & \multirow{2}{*}{0.097} & \multirow{2}{*}{0.923} \\
\hline & $\mathrm{F}$ & 4.18 & 1.13 & & \\
\hline
\end{tabular}

*Statistically significant at $p<0.05$

Table 3: Descriptive statistics of angular measurement for combined male and female samples

\begin{tabular}{|l|c|c|c|c|}
\hline \multicolumn{1}{|c|}{ Parameter } & Mean & SD & Min & Max \\
\hline $\mathrm{N}-\mathrm{Prn} / \mathrm{N}-\mathrm{Pg}$ & 26.84 & 2.09 & 26.40 & 27.28 \\
\hline $\mathrm{N}-\mathrm{Prn}-\mathrm{Cm}$ & 79.01 & 8.65 & 77.20 & 80.82 \\
\hline $\mathrm{Cm}-\mathrm{Sn}-\mathrm{LS}$ & 99.12 & 2.09 & 97.79 & 100.44 \\
\hline $\mathrm{Li}-\mathrm{Sm}-\mathrm{Pg}$ & 126.1 & 6.09 & 124.82 & 127.37 \\
\hline $\mathrm{G}-\mathrm{N}-\mathrm{Nd}$ & 135.49 & 8.15 & 133.78 & 137.19 \\
\hline $\mathrm{G}-\mathrm{Sn}-\mathrm{Pg}$ & 167.56 & 4.26 & 166.66 & 168.44 \\
\hline $\mathrm{N}-\mathrm{Prn}-\mathrm{Pg}$ & 131.27 & 3.06 & 130.62 & 131.90 \\
\hline $\mathrm{N}-\mathrm{Pg} / \mathrm{N}-\mathrm{Ls}$ & 8.13 & 1.64 & 7.79 & 8.47 \\
\hline $\mathrm{Sn}-\mathrm{LS} / \mathrm{Sn}-\mathrm{Pg}$ & 13.18 & 2.38 & 12.67 & 13.67 \\
\hline $\mathrm{N}-\mathrm{Pg} / \mathrm{N}-\mathrm{Li}$ & 4.19 & 1.08 & 3.96 & 4.41 \\
\hline
\end{tabular}

*In degrees 
Graph 1: Comparison of mean angular parameters between male and female subjects

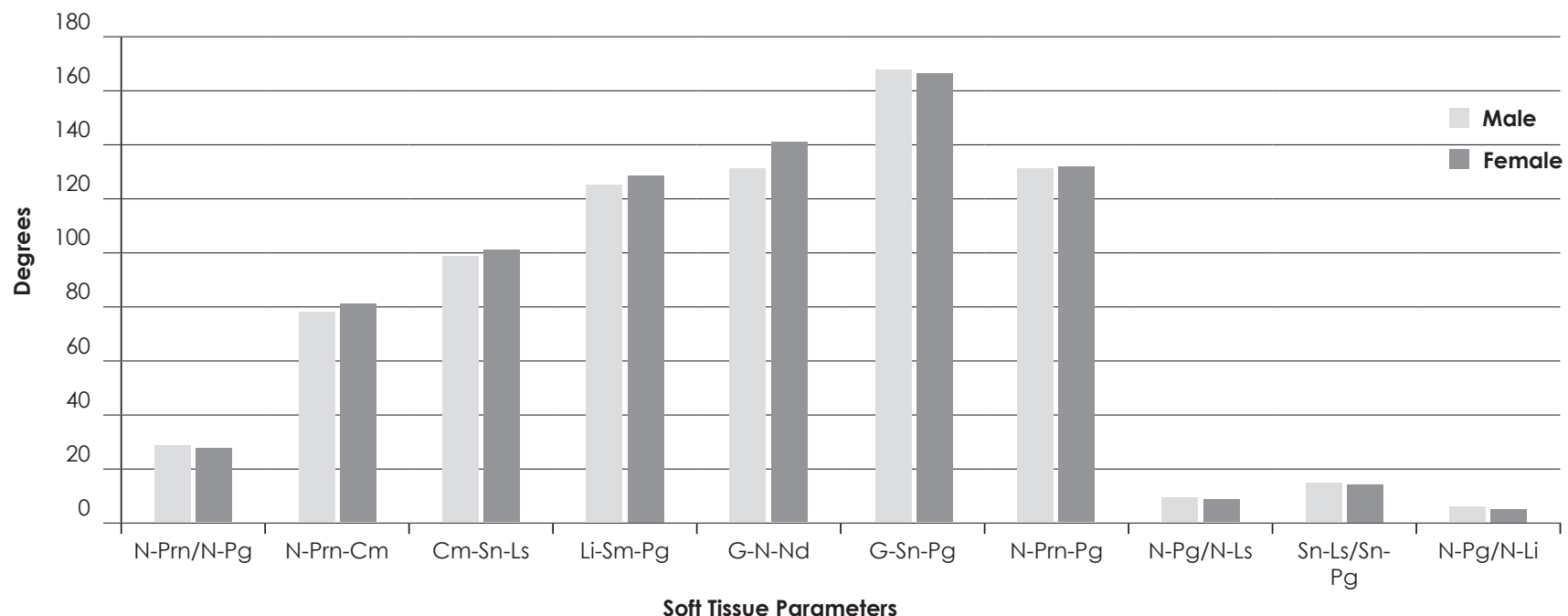

Graph 2: Mean angular parameters in combined male and female subjects

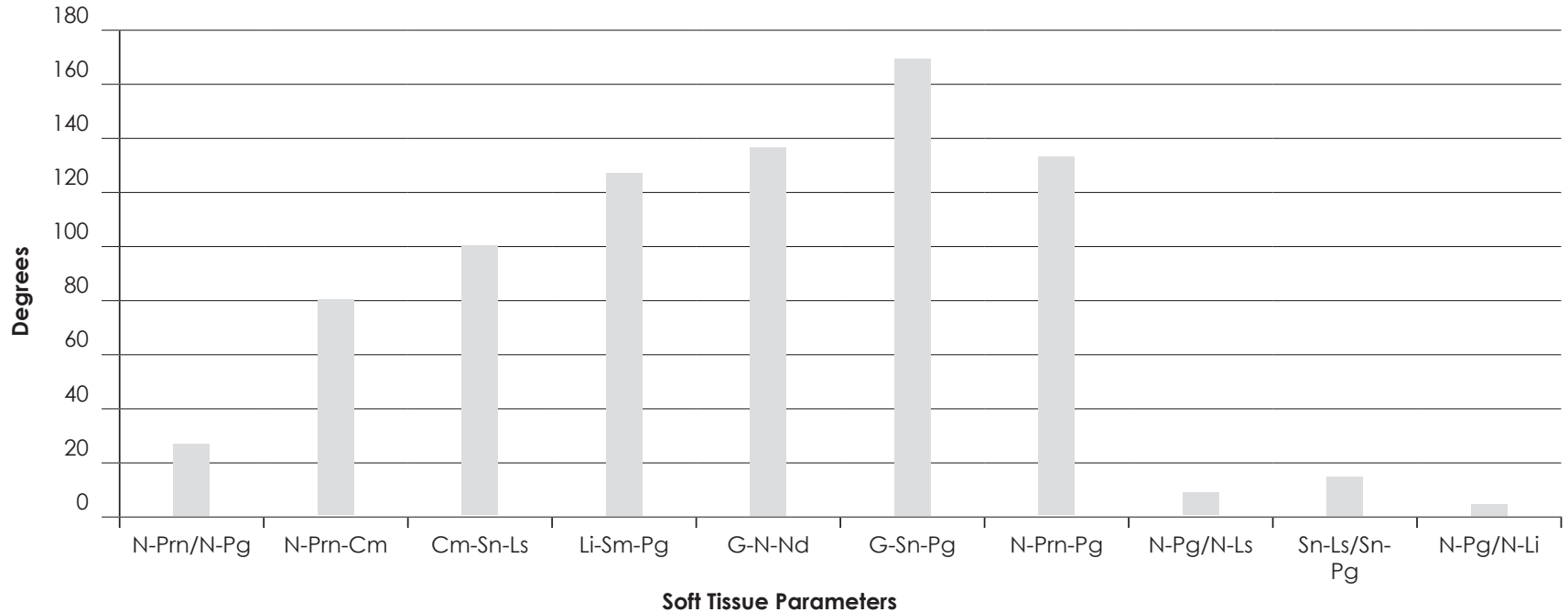

\section{DISCUSSION}

Naso-mental angle (N-Prn/N-Pg) is aesthetically most acceptable within a range of $20^{\circ}-30^{\circ}$. A less prominent nose in relation to chin is preferable in females and the opposite in males. ${ }^{15}$ Clements stated that in most faces illustrated in art throughout the history; nasal prominence angle (naso-mental angle) was around $30^{\circ}$ or less. ${ }^{16}$ In addition, it was also reported that this angle if measured from glabella was within the range of $30^{\circ}-40^{\circ}$. According to Hinds and Kent, the normal value is between $23^{\circ}$ and $37^{\circ} .{ }^{17}$ Milosevic et al did not find any gender difference for this angle with a mean value of $29.97 \pm 2.47^{\circ}$ for Croatian sample.'

Nose tip angle (N-Prn-Cm) determines nose prominence. Lines et al provided a mean range of $60^{\circ}-80^{\circ}$ for the angle of intersection of the nasal dorsum and a tangent to columella. ${ }^{15}$ Milosevic et al found gender difference for this angle with a mean value of $84.12 \pm 5.20^{\circ}$ for females and $79.85 \pm 6.36^{\circ}$ for males. ${ }^{1}$ In the present study the mean nose tip angle was $77.71^{\circ}$ in males and $80.31^{\circ}$ in females with no significant difference.

Naso-labial angle (Cm-Sn-Ls) depends on inclination of upper anteriors. The relationship between nasal base (columella) and upper lip is one of the facial profile parameters with greater clinical uncertainty. The present study did not show any variation between the sexes. Legan and Burstone found no gender difference for this angle; with an average angle of $102^{\circ}$ $\pm 8^{\circ}$ for both genders. They reported naso-labial angle of $74^{\circ} \pm 8^{\circ}$ degrees in a Caucasian adolescent sample with normal facial appearance. ${ }^{18,19}$ Likewise, McNamara et al reported an angle of $102.2^{\circ} \pm 8^{\circ}$ in males and $102.4^{\circ} \pm 8^{\circ}$ in females. ${ }^{20}$ Yuen and Hiranaka reported an angle of $102.7^{\circ} \pm 11^{\circ}$ for males and $101.6^{\circ} \pm 11^{\circ}$ for females in Asian adolescents on standardized photographic 
records, which is almost similar to the present finding. ${ }^{21}$ According to Bergman, for both orthodontic or surgical correction, this angle should be $102^{\circ} \pm 8^{\circ}$. It is important in assessing the upper lip position and is used as a part of extraction decision. ${ }^{22}$ Genecov et al found that the angular parameters of nasal complex between the age of 7-17 years remained relatively constant. ${ }^{23}$ Despite few findings of differences in growth of the nasal complex, the whole nasal contour increased by an average of $3^{\circ}-4^{\circ}$, which is in agreement with the studies of Nanda et $a l^{24}$ Prahl-Andersen et $a l^{25}$ and Ferrario et $a .^{26}$ Milosevic et al found gender difference for this angle, they reported a mean value of $109.39 \pm 7.84^{\circ}$ in females and $105.42 \pm 9.52^{\circ}$ in males.

Mento-labial angle (Li-Sm-Pg) determines the relation of lower lip to soft tissue pogonion and is influenced by the axial inclination of lower incisors. Mento-labial angle also shows great variability. A more pronounced mentolabial angle can be seen in Class II and vertical maxillary deficiency cases. The uprighting of lower incisors tends to enlarge this angle. ${ }^{22}$ Burstone reported the mean value of $122.0^{\circ} \pm 11.7^{\circ}$ for this angle. ${ }^{19}$ In the present sample there was a great gender difference for this angle; the mean values of this study are similar to Zylinski et al. ${ }^{27}$ While Fernández-Riveiro et al; using a similar photogrammetric technique, reported values $3^{\circ}$ higher. ${ }^{11}$ Lines et al, in a study of silhovettes, reported that the mento-labial angle ranged between $120^{\circ}-130^{\circ}$. They found that deeper mento-labial sulcus was preferred in males. In the current study, females had a shallower mento-labial angle than the males. This is in accordance with the profile preferences published by Lines et $a .^{15}$ The ideal face of historical beauties, both male and female had deeper and more pronounced mentolabial sulci of around $122^{\circ}$. Milosevic reported a mento-labial angle of $132.02 \pm 9.63^{\circ}$ in a Croatian sample with normal facial appearance, and showed gender difference.'

Naso-frontal angle (G-N-Nd) determines the angulation of nose on face which plays a major role in facial appearance. The present study showed gender dimorphism indicating a prominent nose in males, leading to more convex profile. Epker $^{7}$ found no gender difference in Caucasians, while Milosevic et al found gender difference for this angle. They reported a mean value of $139.11 \pm 6.35^{\circ}$ in females and $136.38 \pm 6.7^{\circ}$ in males.

Angle of facial convexity excluding nose (G-Sn-Pg) is used to assess convexity or concavity of the profile, which is not affected by nose prominence. Milosevic reported mean angle as $168.92 \pm 4.80^{\circ}$ without any gender difference. ${ }^{\prime}$ Angle of facial convexity including nose (N-Prn-Pg) reflects either a vertical growth of tip of the nose or a more forward movement of soft tissue pogonion. Peck \& Peck studied cephalometric and photographic records of Caucasians with pleasing faces. They used facial angle T-P/N-Pg $\left(102.5 \pm 3^{\circ}\right)$ to describe the profile orientation. Both angles complete the facial (G-Sn-Pg) and total facial (G-Prn-Pg) convexity angles. ${ }^{10}$ Burstone used an angle called 'total facial contour', which was defined as the intersection of upper facial (G-Sn) and anterior lower facial (Sn-Pg) components. ${ }^{28}$ Arnett and Bergman presented facial analysis based on previous studies and surgical experience. The angle G-Sn-Pg was used to assess the convexity/concavity of the profile.8.9 According to the authors, Class I profile presented an angle range of $165^{\circ}-175^{\circ}$, Class II profile less than $165^{\circ}$, and Class III greater than $175^{\circ}$. Fernández-Riveiro et al found higher values for males $\left(140^{\circ} \pm 5^{\circ}\right)$ than females $\left(139^{\circ} \pm 4.5^{\circ}\right)$ because they measured from glabella, not from nasion. However, there were no significant gender difference. ${ }^{11}$ Yuen and Hiranaka also found no gender dimorphism (males: $135^{\circ} \pm 4^{\circ}$; females: $135^{\circ} \pm 3^{\circ}$ ). ${ }^{21}$ Bishara et al measured the angle from glabella, and stated that between $25-45$ years of age, the angle increased by $2.1^{\circ}$ in males and $1.3^{\circ}$ in females, reflecting either a more vertical growth of the tip of the nose or more forward movement of soft tissue pogonion. ${ }^{29}$ Milosevic reported a total facial angle or facial convexity including the nose (N-Prn-Pg) as $130.5 \pm 3.7^{\circ}$ in males and $130.2 \pm 3.5^{\circ}$ in females, indicating no gender difference. 'The present report are similar to the findings of Subtenly, ${ }^{30}$ Cox and Van der Linden, ${ }^{31}$ Nanda et al, ${ }^{24}$ Arnett et al. ${ }^{32}$

Projection of upper lip to chin (N-Pg/N-Ls) is the position of upper incisors and the thickness of soft tissue overlying these teeth. ${ }^{32}$ Milosevic reported a mean angle of $7.08 \pm 2^{\circ}$ in a Caucasian sample with no gender difference. ${ }^{\prime}$ The present finding indicates a more prominent upper lip in coastal Andhra population when compared to Caucasians. Upper lip angle (Sn-Ls/Sn-Pg) shows the position upper lip in reference to soft tissue subnasale and is a reflection of axial inclination of upper incisors. Milosevic reported a mean angle of $12.33 \pm 5.52^{\circ}$ without any significant gender difference.

Projection of lower lip to chin $(\mathrm{N}-\mathrm{Pg} / \mathrm{N}-\mathrm{Li})$ reflects the position of lower incisors and thickness of the soft tissue overlying these teeth. The upper and lower lip angle $(\mathrm{N}-$ $\mathrm{LS} / \mathrm{N}-\mathrm{Pg}$ and $\mathrm{N}-\mathrm{Li} / \mathrm{N}-\mathrm{Pg}$ ) was measured from nasion. The upper lip was also measured from subnasal. ${ }^{32}$ In the present study, the upper lip angle, measured from subnasal ( $\mathrm{Sn}$ Ls/Sn-Pg) showed no gender differences, while Arnett et al found this angle to be greater in females. ${ }^{32}$ Milosevic reported a mean angle of $3.49 \pm 1.60^{\circ}$ without significant gender difference. 


\section{CONCLUSION}

The mean values obtained from this sample can be used for comparison with records of subjects with the same characteristics following the same photographic analysis.

The present study revealed that the males of Coastal Andhra Pradesh have a mild convex profile with prominent nose where as females also have a mild convex profile but due to a recessive chin. A higher upper lip prominence was seen in males as compared to Caucasian.

\section{REFERENCE}

1. Milosevic AS, Lapter VM, Slaj M. Analysis of the soft tissue facial profile by means of angular measurements. Eur J Orthod 2008; 30:135-40.

2. Arnett WG, Gunson MJ, McLaughlin RP. The Essence of Beauty. American Association of Orthodontists 2004.

3. Malkoc S, Demi A, Uysal T, Canbuldu N. Angular photogrammetric analysis of the soft tissue facial profile of Turkish adults. Eur J Orthod $2009 ; 31: 174-79$.

4. Mandall N A, McCord J F, Blinkhorn A S, Worthington H V. Perceived aesthetic impact of malocclusion and oral self perceptions in 14-15 year-old Asian and Caucasian children in Greater Manchester. Eur J Orthod 2000; 21:175-83.

5. Stoner M. A photometric analysis of the facial profile. Am J Orthod Dentofac Orthop 1955; 41:453-69.

6. Neger MA. A quantitative method for the evaluation of the soft tissue facial profile. Am J Orthod Dentofac Orthop 1959; 45:738-51.

7. Epker B N. Adjunctive esthetic surgery in the orthognathic surgery patient. Craniofac Gr Series 1992; $187-216$.

8. Arnett GW, Bergman RT. Facial keys to orthodontic diagnosis and treatment planning. Part I. Am J Orthod Dentofac Orthop 1993; 103:299-312.

9. Arnett GW, Bergman RT. Facial keys to orthodontic diagnosis and treatment planning. Part II. Am J Orthod Dentofac Orthop 1993: 103:395-411.

10. Peck H, Peck S. A concept of facial esthetics. Angle Orthod 1970; 40:284-318.

11. Fernandez-Riveiro P, Smyth-Chamosa E, Suarez-Quintanilla D, Suarez-Cunqueiro M. Angular photogrammetric analysis of the soft tissue facial profile. Eur J Orthod 2003; 25:393-99.

12. Peerlings RHJ, Kuijpers-Jagtman AM, Hoeksma JB. A photographic scale to measure facial aesthetics. Eur J Orthod 1995; $17: 101-09$.

13. Malkoc S, Sumez NU, Nur M, Donaghy CE. Reproducibility of airway dimensions of tongue and hyoid position on lateral cephalograms. Am J Orthod Dentofac Orthop 2005; 128:513-16.

14. Scavone H, Trevisan Ho Jr, Garib DG Jr, Ferreira FV. Facial profile evaluation in Japanese-Brazilian adults with normal occlusions and well-balanced faces. Am J Orthod Dentofac Orthop 2006; 129: 721.el-721.e5.

15. Lines PA, Lines RR, Lines CA. Profilemetrics and facial esthetics. Am J Orthod Dentofac Orthop 1978; 73:648-57.

16. Clements B S. Nasal imbalance and the orthodontic patient. Am J Orthod Dentofac Orthop 1969; 55: 244-64.

17. Hinds E C, Kent J N. Surgical treatment of developmental jaw deformities. C.V. Mosby Company, St. Louis. 1972.

18. Legan HL, Burstone CJ. Soft tissue cephalometric analysis for orthognathic surgery. J Oral Surg 1980; 38:744-51.

19. Burstone CJ. Lip posture and its significance in treatment planning. Am J Orthod Dentofac Orthop 1967; $262-89$.

20. McNamara JA, Brust EW, Riolo ML. Soft tissue evaluation of individuals with an ideal occlusion and well-balanced face. Craniofac Gr Series 1993; 115-46.

21. Yuen SWH, Hiranaka K. A photographic study of the facial profiles of southern Chinese adolescents. Quintessence Int. $1989 ; 20: 665-76$.

22. Bergman RT. Cephalometric soft tissue facial analysis. Am J Orthod Dentofac Orthop 1999; 116:373-89.

23. Genecov JS, Sinclair PM, Dechow PC. Development of the nose and soft tissue profile. Angle Orthod 1989; 60:191-98.

24. Nanda RS, Meng H, Kapila S, Goohuis J. Growth changes in the soft tissue facial profile. Angle Orthod 1990; 60:177-90.

25. Prahl Andersen B, Ligthelm Bakker, Wattel E, Nanda R. Adolescent growth changes in soft tissue profile. Am J Orthod Dentofac Orthop 1995; 107:476-83.

26. Ferrario VF, Sforza C, Poggio CE, Schmitz JH. Soft-tissue facial morphometry from 6 years to adulthood: a three-dimensional growth study using a new modeling. PI Reconst Surg 1999; 103:768-78.

27. Zylinski CG, Nanda RS, Kapila S. Analysis of soft tissue facial profile in white males. Am J Orthod Dentofac Orthop 1992; 101:514-518.

28. Burstone CJ. The integumental profile. Angle Orthod 1959; 29:93-104.

29. Bishara SE, Jacobsen JR, Hession TJ, Treder JE. Soft tissue profile changes from 5-45 years of age. Am J Orthod Dentofac Orthop 1998; 114:698-706.

30. Subtelny JD. A longitudinal study of soft tissue facial structures and their profile characteristics defined in relation to underlying skeleta structures. Am J Orthod Dentofac Orthop 1959; 45:481-507.

31. Cox NH, Van derLinden FPGM. Facial harmony. Am J Orthod Dentofac Orthop 1971; 60:175-83.

32. Arnett GW. Soft tissue cephalometric analysis: Diagnosis and treatment planning of dentofacial deformity. Am J Orthod Dentofac Orthop 1999; 116:239-53. 